\title{
Proteolytic and lipolytic microbiota of refrigerated raw milk from northeast and southern regions of Brazil
}

\section{Microbiota proteolítica e lipolítica de leite cru refrigerado da região nordeste e sul do Brasil}

\author{
Jose Carlos Ribeiro Junior $^{1 *}$; Joyce Bitencourt Atayde Lima²; \\ Kleydejany Lima de Lemos'; Livia Cavaletti Corrêa da Silva ${ }^{3}$; \\ Ronaldo Tamanini'; Vanerli Beloti ${ }^{5}$
}

\begin{abstract}
The shelf life of milk and milk derivatives is directly related to the microbiological quality of refrigerated raw milk. Spoilage microorganisms with proteolytic and/or lipolytic properties are primarily responsible for the decrease in the quality of milk, which is reflected in the shelf life of pasteurized milk and all derivatives. The aim of this study was to determine the spoilage microbial load of refrigerated raw milk from the northeast and southern regions of Brazil, which have different climatic and technological conditions of production. We evaluated 46 samples of milk from the state of Paraná in the southern region, and 10 samples of milk from the state of Maranhão in the northeast region, totaling 56 samples collected from November 2013 to November 2014. The producers of Paraná were divided into large (20) or small (26) according to the average daily production. All producers of Maranhão were considered small $(<500 \mathrm{~L} /$ day). The proteolytic and lipolytic microorganism counts were conducted in milk agar and tributyrin agar, respectively. Milk from the large producers of Paraná had average counts of 1.4 $\times 10^{4} \mathrm{CFU} / \mathrm{mL}$ for proteolytic microorganisms and $1.2 \times 10^{3} \mathrm{CFU} / \mathrm{mL}$ for lipolytics microorganisms, significantly $(\mathrm{p}<0.05)$ lower than the small producers in the same state, and the producers of Maranhão. Producers of Maranhao had counts of $1.1 \times 10^{5} \mathrm{CFU} / \mathrm{mL}$ for proteolytic microorganisms and $2 \times 10^{5}$ $\mathrm{CFU} / \mathrm{mL}$ for lipolytic microorganisms, with the proteolytic count significantly lower than that of small Paraná producers. The amount of proteolytic and lipolytic spoilage microorganisms in milk is influenced by the adaptation of the microorganisms to cold, promoted by the cooling of milk, which is practiced less frequently in the country's northeastern region. The amount of spoilage microorganisms is also affected by the implementation of milking hygiene practices, which reduce contamination. Such practices are more frequently and efficiently implemented among large producers with more advanced technology, which can improve the microbiological quality of raw milk, thus increasing the shelf life of pasteurized milk, and reducing problems in UHT milk as well as milk derivatives.
\end{abstract}

Key words: Lipolysis, proteolysis, shelf life, spoilage

\section{Resumo}

\footnotetext{
${ }^{1}$ Discente de Doutorado em Ciência Animal, Universidade Estadual de Londrina, UEL, Londrina, PR, Brasil. E-mail: jcribeiro. vet@hotmail.com

${ }^{2}$ Prof ${ }^{\text {as }}$, Instituto Federal do Maranhão, IFMA, Maranhão, Brasil. E-mail: joyce.lima@ifma.edu.br; kleydejany@ifma.edu.br.

${ }^{3} \mathrm{Dr}^{\mathrm{a}}$ em Ciência Animal, Fiscal Federal Agropecuário, Laboratório Nacional Agropecuário, LANAGRO, Campinas, SP, Brasil. E-mail: liviacavaletti@gmail.com

${ }^{4}$ Dr. em Ciência Animal, Dept ${ }^{\mathrm{o}}$ de Medicina Veterinária Preventiva, DMVP, UEL, Londrina, PR, Brasil. E-mail: ronaldot@uel.br

${ }^{5}$ Prof $^{\mathrm{a}} \mathrm{Dr}^{\mathrm{a}}$, Dept ${ }^{\mathrm{O}}$ de Medicina Veterinária Preventiva, DMVP, UEL, Londrina, PR, Brasil. E-mail: vbeloti@uel.br

* Author for correspondence
} 
A vida útil do leite e de seus derivados está diretamente relacionada à qualidade microbiológica do leite cru refrigerado. Os micro-organismos deteriorantes proteolíticos e/ou lipolíticos são os principais responsáveis pela diminuição da qualidade tecnológica do leite, repercutindo na vida útil do leite pasteurizado, UHT e todos os derivados. Nesse contexto, o objetivo do presente trabalho foi determinar a carga microbiana deteriorante do leite cru refrigerado das regiões nordeste e sul do Brasil, que apresentam diferentes condições climáticas e tecnológicas de produção. Foram avaliadas 46 amostras de leite do estado do Paraná, região sul, e 10 amostras do Maranhão, região nordeste, totalizando 56 amostras coletadas no período de novembro de 2013 a novembro de 2014. Os produtores paranaenses foram divididos entre grandes (20) ou pequenos (26) de acordo com a produção diária média. Todos os produtores do estado do Maranhão foram considerados pequenos ( $<500 \mathrm{~L} / \mathrm{dia})$. Foi realizada a contagem de micro-organismos proteolíticos e lipolíticos em ágar leite e ágar tributirina, respectivamente. O leite oriundo dos grandes produtores do estado do Paraná apresentou contagens médias de $1,4 \times 10^{4} \mathrm{UFC} / \mathrm{mL}$ para proteolíticos e $1,2 \times 10^{3} \mathrm{UFC} / \mathrm{mL}$ para lipolíticos, significativamente $(\mathrm{p}<0,05)$ mais baixas em relação pequenos produtores do mesmo estado, e também menores que as contagens dos produtores maranhenses. Os produtores do estado do Maranhão apresentaram contagens de $1,1 \times 10^{5} \mathrm{UFC} / \mathrm{mL}$ para proteolíticos e $2 \times 10^{5} \mathrm{UFC} / \mathrm{mL}$ para lipolíticos, com contagem de proteolíticos significativamente inferior à apresentada por pequenos produtores do Paraná. As contagens de microorganismos deteriorantes proteolíticos e lipolíticos no leite são influenciadas pela adaptação desses micro-organismos ao frio, promovido pela refrigeração do leite, menos frequente na região nordeste do país, bem como pela implantação de práticas de higiene de ordenha, que diminuem a contaminação por estes e outros micro-organismos. Tais práticas são mais frequentes e eficientes entre os grandes produtores que apresentam maior tecnificação na produção, melhorando a qualidade microbiológica do leite cru e, consequentemente, a vida útil do leite pasteurizado, reduzindo problemas tecnológicos no leite UHT e derivados lácteos.

Palavras-chave: Deteriorantes, lipólise, proteólise, vida útil

\section{Introduction}

Brazil is the fourth largest producer of milk in the world (FAO, 2013); however, there are still problems with quality and productivity. The most prominent problem with the quality of milk is the excessive contamination of raw milk, which leads to rapid deterioration of the products, including pasteurized and UHT milk (TAMANINI, 2012). Thus, pasteurized milk in Brazil has an average shelf life of five days, while milk produced in the USA can last up to 20 days. This greatly decreases the competitiveness of Brazilian milk in the international market. The spoilage of refrigerated milk is mainly due to bacterial activities on the protein and fat found in milk (SANTANA et al., 2001).

There are variations of microbiological quality between large and small milk producers (RIBEIRO JÚNIOR et al., 2015), and between different regions of the country. The Normative Instruction n. 62, which regulates the quality control of refrigerated raw milk in Brazil, determines different microbiological parameters in milk produced in northern and northeastern Brazil (BRASIL, 2011).

Much of the country's dairy farmers consists of small and medium producers, with low production and productivity (OHI, 2010). However, in certain dairy regions such as Castro and Paraná, there are dairy farms that produce thousands of liters of milk per day, with bacterial counts from less than 10,000 Colony Forming Units (CFU)/mL, which meets the strictest international quality standards, to 100,000 CFU/mL (USA, 2003; EUROPEAN UNION, 2004). This is due to the technification of the properties, careful milking hygiene, the cooling rate of milk and effective technical advice.

The cooling of milk controls the mesophilic microbiota, which are predominantly saccharolytic. These bacteria degrade lactose to lactic acid, and promotes the acidification of milk (TRONCO, 2008). Milk 
cooling conditions can also stop the development of psychrotrophic microorganisms, whose metabolism is predominant proteolytic and lipolytic (SANTANA et al., 2001). Cooling will not solve problems with milk quality, and must be accompanied by good hygienic practices during milking.

Bacterial proteolytic enzymes, similar to chymosin, act mostly on $\kappa$-casein, resulting in the destabilization of casein micelles, and the coagulation of milk (FAIRBAIRN; LAW, 1986; RECIO et al, 2000). This category of enzymes plays a role in various problems in the food industry, including sedimentation and gelation of UHT milk, formation of undesirable amino acids during cheese ripening, and the development of bitterness in milk and milk products (CELESTINO et al., 1997).

Lipolysis results from the action of natural lipases and/or microbial enzymes. These enzymes have the property of hydrolyzing triglyceride fat constituents of short chain fatty acids, including butyric, caproic, caprylic, and capric acids, and are primarily responsible for the appearance of unpleasant odors in milk. For example, lipases have been shown cause rancidity in cheese (CHEN et al., 2003).

Some of the proteolytic and lipolytic microorganisms found in milk, such as the genus Bacillus, are resistant to pasteurization (RIBEIRO JÚNIOR et al., 2014, 2015). Thus, there is a close relationship between the load of microorganisms that produce spoilage enzymes in raw milk, and the shelf life of products (SANTANA et al., 2001).

In Brazil, there are few studies determining the total count of spoilage microorganisms in milk. The objective of this study is to determine the proteolytic and lipolytic microbiota of refrigerated raw milk in southern and northeastern Brazil.

\section{Materials and Methods}

We evaluated 20 samples of refrigerated raw milk from large producers. We also evaluated
26 samples of refrigerated raw milk from small producers in the state of Paraná, southern Brazil, and 10 samples from small producers in the state of Maranhão, northeastern Brazil, for a total of 56 samples. In Paraná, the samples were collected from large producers in the municipalities of Castro and Arapoti, and small producers in the municipalities of Londrina, Sertanópolis, Bela Vista do Paraiso, Arapongas and Tamarana. Samples from Maranhão were collected in the municipalities of Bacabal, Codó, Peritoró, and Timon.

Large producers were defined as having a production rate of up to 5000 liters per day, and small producers with a production rate of up to 500 liters per day. Small producers generally possessed manual or foot controlled mechanical milking bucket systems. In Paraná, the small producers cooled the milk in immersion or expansion tanks. In Maranhão, $80 \%$ of the producers did not cool their milk. All major producers had channeled the milking and cooling system in the expansion tank, and two producers had pre-cooling technology in a plate system.

Samples from Paraná were analyzed at the Inspection Laboratory Animal Products at the State University of Londrina and samples from Maranhão were anaylzed at the Federal Institute of Microbiology Laboratory of Maranhão, Caxias campus. The samples were collected with the aid of a shell for collecting previously sterilized samples. The milk from the cooling tanks or cans was undercooled, and transported in sterile bottles to the laboratories. Samples were collected from November 2013 to November 2014.

Serial dilutions of the samples were performed in saline $(0.85 \%)$ peptone $(0.1 \%)$ water, and seeded in duplicate milk agar $(9: 1)$ supplemented with skim milk powder solution (10\%), and tributyrin agar (99: 1) supplemented with tributyrin for the counting of proteolytic and lipolytic bacteria, respectively (BEERENS; LUQUET, 1990). The plates were incubated at $32 \pm 1^{\circ} \mathrm{C}$ for 48 hours 
(FRANK; YOUSEF, 2004). Only colonies with translucent halos were counted.

The counts were converted into logarithmic scale, and we used the Student $t$-test in Microsoft Excel $^{\circledR} 2010$ with $\alpha=5 \%$ to calculate significance.

\section{Results and Discussion}

The mean count for the total samples evaluated were $5 \times 10^{5} \mathrm{CFU} / \mathrm{mL}$ for proteolytic bacteria, and $8.6 \times 10^{5} \mathrm{CFU} / \mathrm{mL}$ for lipolytic bacteria (Tables 1 and 2). Milk from the large producers in Paraná had counts of $1.4 \times 10^{4} \mathrm{CFU} / \mathrm{mL}$ and $1.2 \times 10^{3} \mathrm{CFU} / \mathrm{mL}$ for proteolytic and lipolytic bacteria, respectively.
These counts are low compared to the counts in the milk samples from small producers in the same state, which had average counts of $1 \times 10^{6} \mathrm{CFU} / \mathrm{mL}$ and $1.8 \times 10^{6} \mathrm{CFU} / \mathrm{mL}$ for proteolytic and lipolytic bacteria, respectively.

Comparing the results from the large and small producers in the state of Paraná, one can observe a significant difference $(\mathrm{p}=0.0002)$ in proteolytic bacteria counts. There are also significant differences in the counts of proteolytic bacteria between the large producers and the small producers of Maranhão ( $p$ $=0.04$ ), and between the small producers of Paraná and the small producers of Maranhão $(p=0.0007)$ (Table 1).

Table 1. Proteolytic microorganisms of refrigerated raw milk samples from small and large producers of Parana state (PR) and small producers of Maranhão state (MA), Brazil, from November 2013 to November 2014.

\begin{tabular}{|c|c|c|c|c|}
\hline & Small (PR) & Large (PR) & Small (MA) & All the samples \\
\hline Minimum (CFU/mL) & $2.1 \times 10^{3}$ & $4 \times 10^{1}$ & $1,5 \times 10^{4}$ & $4 \times 10^{1}$ \\
\hline Maximum (CFU/mL) & $4.6 \times 10^{6}$ & $2.7 \times 10^{5}$ & $3.6 \times 10^{5}$ & $4.6 \times 10^{6}$ \\
\hline Mean* $^{*}$ CFU/mL) & $1 \times 10^{6 \mathrm{a}}$ & $1.4 \times 10^{4 b}$ & $1.1 \times 10^{5 \mathrm{c}}$ & $5 \times 10^{5}$ \\
\hline Median $(\mathrm{CFU} / \mathrm{mL})$ & $5.1 \times 10^{5}$ & $1.3 \times 10^{3}$ & $5.5 \times 10^{4}$ & $3 \times 10^{4}$ \\
\hline Standard deviation & $\pm 1.2 \times 10^{6}$ & $\pm 5.7 \times 10^{4}$ & $\pm 1.3 \times 10^{5}$ & $\pm 9.6 \times 10^{5}$ \\
\hline
\end{tabular}

${ }^{*}$ Values followed by different numbers in the same row differ by Student's $t$ test at $5 \%$ probability.

There was a significant difference in the counts of lipolytic bacteria ( $p=0.01$ ) between samples from the Maranhão producers and those from the large producers of Paraná state, and between the small and large producers Paraná $(\mathrm{p}=0.07)$, but not between the small producers of the two states $(\mathrm{p}=$ 0.1) (Table 2).

Table 2. Lipolytic microorganisms of refrigerated raw milk samples from small and large producers of Parana state (PR) and small producers of Maranhão state (MA), Brazil, from November 2013 to November 2014.

\begin{tabular}{ccccc}
\hline & Small (PR) & Large (PR) & Small (MA) & All the samples \\
\hline Minimum $(\mathrm{CFU} / \mathrm{mL})$ & $5 \times 10^{2}$ & $2 \times 10^{2}$ & $2.7 \times 10^{4}$ & $2 \times 10^{2}$ \\
Maximum $(\mathrm{CFU} / \mathrm{mL})$ & $2.5 \times 10^{7}$ & $5.5 \times 10^{3}$ & $6.3 \times 10^{5}$ & $2.5 \times 10^{7}$ \\
Mean $^{*}(\mathrm{CFU} / \mathrm{mL})$ & $1.8 \times 10^{6 \mathrm{ab}}$ & $1.2 \times 10^{3 \mathrm{a}}$ & $2 \times 10^{5 \mathrm{~b}}$ & $8.6 \times 10^{5}$ \\
Median $(\mathrm{CFU} / \mathrm{mL})$ & $2 \times 10^{5}$ & $9 \times 10^{2}$ & $1.2 \times 10^{5}$ & $2.7 \times 10^{4}$ \\
Standard deviation & $\pm 4.9 \times 10^{6}$ & $\pm 1.1 \times 10^{3}$ & $\pm 2.1 \times 10^{5}$ & $\pm 3.4 \times 10^{6}$ \\
\hline
\end{tabular}

*Values followed by different numbers in the same row differ by Student's t-test at $5 \%$ probability. 
Figure 1 shows the distribution of these counts. As for the counts of proteolytic bacteria, $75 \%$ of the samples from the large producers were below the minimum count found in samples from the small producers in the state of Paraná, and $100 \%$ were below the minimum counts observed in samples from the producers of Maranhao. Over $75 \%$ of the counts of lipolytic bacteria from small producers of Paraná were above the maximum count observed in samples from the large producers. Samples from the producers of Maranhão also had higher counts of lipolytic bacteria than samples from the large producers.

Figure 1. Distribution of proteolytic (Prot.) and lipolytic (Lipo) microorganisms counts (log) in refrigerated raw milk samples from large (A) and small (B) producers of Paraná state (PR) and small producers (C ) of Maranhão state (MA) from November 2013 to November 2014.

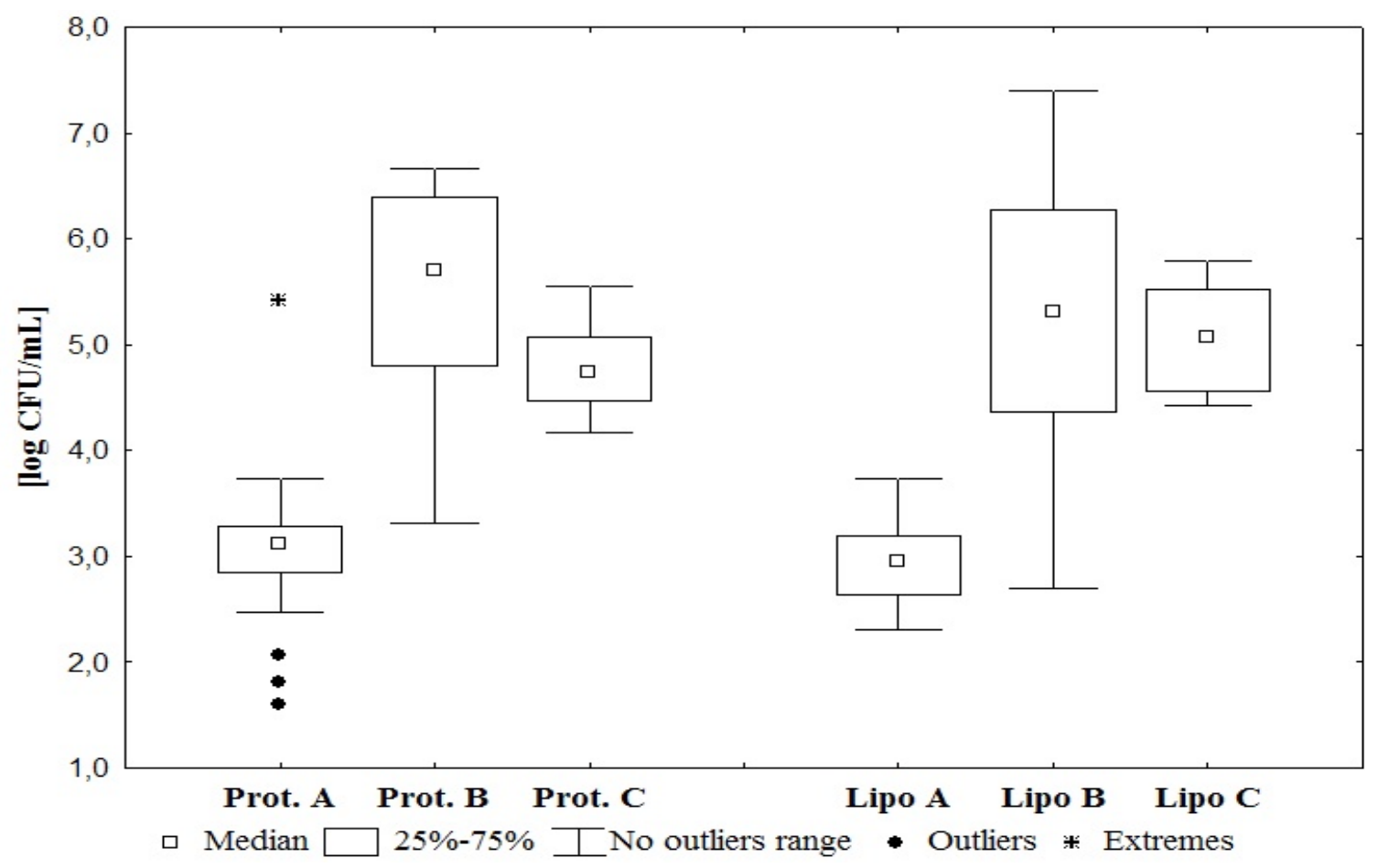

The producers from the state of Maranhão had mean counts of $1.1 \times 10^{5} \mathrm{CFU} / \mathrm{mL}$ and $2 \times$ $10^{5} \mathrm{CFU} / \mathrm{mL}$ for proteolytic and lipolytic bacteria respectively, which is lower than the small producers from the state of Paraná. This difference may be related to the adaptation of microbiota composition in response to cooling temperatures. In the entire region of southern Brazil, including the state Paraná, milk cooling has been implemented for years, even prior to the legal implementation of IN 51 (BRASIL, 2002). In contrast to the milk from Maranhao where small producers rarely cool milk, cooling practices may have led to the selection of psychrotrophic microorganisms in the milk produced in Paraná, resulting in the predominance of mesophilic microorganisms with primarily saccharolytic metabolism (NERO et al., 2009).

The high level of contamination in the milk from the small producers of Paraná despite the implementation of cooling was not associated with the adoption of hygienic practices during milking, but could be due to an adaptation of microorganisms to new growth condition. Thus, it is not surprising 
that milk from small producers in the state of Paraná presented higher counts of proteolytic and lipolytic micro-organisms compared to milk from Maranhão producers. Proteolytic and/or lipolytic metabolisms predominate in bacteria adapted to growth under refrigeration temperatures, which are considered psychrotrophic (SANTANA et al., 2004).

The significantly lower counts observed in milk from the large producers in relation to those from the small can be attributed mainly to differences in production conditions, which are also reflected in the quality of milk produced (RIBEIRO JÚNIOR et al., 2014, 2015). It is common in Maranhão state and in northeastern regions of Brazil for milk to be produced in dairy farms that do not yet meet all the legal requirements for milk production (NERO et al., 2005). In contrast, the large milk producers of southern and southeastern Brazil have higher technical standards in farms, ensuring animal productivity and nutritional values of milk (RIBEIRO JÚNIOR et al., 2014). They also have high standards of hygienic practices during milking (VALLIN et al., 2009; MATSUBARA et al., 2011; BELOTI et al., 2012) and suitable refrigeration equipment.

Mattos et al. (2010) found that $83 \%$ of dairy farms in Pernambuco, northeastern Brazil, produced milk with microbial counts greater than $10^{6} \mathrm{CFU} /$ $\mathrm{ml}$ due to poor hygiene practices during milking, the predominance of manual milking, and a lack of milk cooling. Silva et al. (2011) found that the main points of microbiological contamination of milk are, in descending order, residual brass water, brass bottoms, coolers, ceilings, jets, liners, buckets and hands of the milker. Controlling the microbial contamination of milk at these points of contact (MATTOS et al., 2010) is considered to be the main obstacle to meeting the Brazilian legal parameters (BRASIL, 2011). Another factor that discourages the implementation of best milking practices is the lack of monetary incentive for high quality milk (BELOTI et al., 2013).
The observed differences in microbial counts are dependent more on the conditions of production and the application of appropriate hygienic practices than the region of production. Control of spoilage microorganisms in raw milk is directly related to the reduction of mesophilic microbial load (RIBEIRO JÚNIOR et al., 2014, 2015). Therefore, counts of proteolytic and lipolytic bacteria are lower among the large milk producers, and higher among the small producers regardless of regional location. Furthermore, the practice of refrigeration in southern Brazil may have resulted in the selection for proteolytic and lipolytic psychrotrophic microorganisms, which have adapted to colder temperatures and can grow quickly, thus reducing the cooling efficiency in controlling microbial growth and increasing the deterioration of refrigerated milk produced by small dairy farms in the region.

Our study indicates that the same control for mesophilic microorganisms are needed for control of psychrotrophic microbiota, namely proteolytic and lipolytic bacteria, and need to be implemented urgently by small farmers in both regions studied. Cooling as an isolated tool has compromised efficiency when microbial contamination is high due to bacterial adaptations. Monetary incentive for high milk quality can encourage farmers to adopt higher standards of practices in milk production and elevate the standards of milk to legal parameters.

\section{References}

BEERENS, H.; LUQUET, F. M. Guía practico para el análisis microbiológico de la leche y los productos lácteos. Zaragoza: Editorial Acríbia S.A., 1990. 141 p.

BELOTI, V.; BATTAGLinI, A. P. P.; FAGNANI, R.; DUNGA, K. S. Difusão de boas práticas e caracterização de propriedades leiteiras. Archivos de Zootecnia, Córdoba, v. 62, n. 237, p. 151-154, 2013.

BELOTI, V.; RIBEIRO JÚNIOR, J. C.; TAMANINI, R.; SILVA, L. C. C. Impacto da implantação de boas práticas de higiene na ordenha sobre a qualidade microbiológica e físico-química do leite cru refrigerado. Revista do Instituto de Laticinios Cândido Tostes, Juiz de Fora, v. 67, n. 388, p. 5-10, 2012. 
BRASIL. Ministério da Agricultura, Pecuária e Abastecimento. Instrução Normativa $\mathrm{n}^{\circ} 51$, de 20 de setembro de 2002. Aprova os regulamentos técnicos de produção, identidade e qualidade do leite. Diário Oficial [da] República Federativa do Brasil, Brasília, 21 set. 2002, Seção 1, p. 13.

Ministério da Agricultura, Pecuária e Abastecimento. Instrução Normativa $n^{\circ}$ 62, de 29 de dezembro de 2011. Diário Oficial [da] República Federativa do Brasil, Brasília, 31 dez. 2011. Seção 1, p. 6.

CELESTINO, E. L.; IYER, M.; ROGINSKI, H. Reconstituted uht-treated milk: effects of raw milk, powder quality and storage conditions of uht milk on its physico-chemical attributes and flavor. International Dairy Journal, Edmonton, v. 7, n. 2, p. 129-140, 1997.

CHEN, L.; DANIEL, R. M.; COOLBEAR, T. Detection and impact of protease and lipase activities in milk and milk powders. International Dairy Journal, Edmonton, v. 13, n. 4, p. 255-275, 2003.

UNITED STATES - USA. Grade "A" pasteurized milk ordinance (2003 revision): standards for grade "A" milk and milk products. Silver spring: FDA - United States Food and Drugs Administration, Center for Food Safety and Applied Nutrition, Section 7, 2003. Available at: <http://www.cfsan.fda.gov/ ear/pmo03-2.html >. Accessed at: 30 may 2014.

FAIRBAIRN, D. J.; LAW, B. A. Protease of psycrotrophic bacteria: their production, properties, effects and control. Journal of Dairy Research, Copenhagen, v. 53, n. 1, p. 139-177, 1986.

FOOD AND AGRICULTURE ORGANIZATION OF UNITED NATIONS - FAO - FAOSTAT. Countries by commodity. Roma: FAO, 2013. Available at: < http:// faostat.fao.org/site/339/default.aspx > . Accessed at: 3 jan. 2013.

FRANK, J. F.; YOUSEF, A. E. Test for groups of microrganisms. In: WEHR, H. M.; FRANK, J. K (Ed.). Standard methods for the examination of dairy products. $17^{\text {th }}$ ed. Washington, D.C.: American Public Health Association, 2004. Chapter 8, Section 8.090 an 8.100, p. 239-242.

MATSUBARA, M. T.; BELOTI, V.; TAMANINI, R.; FAGNANI, R.; SILVA, L. C. C.; MONEIRO, A. A.; BATAGLINNI, A. P. P.; ORTOLANI, M. B. T.; BARROS, M. A. F. Boas práticas de ordenha para redução da contaminação microbiológica do leite no agreste Pernambucano. Semina: Ciências Agrárias, Londrina, v. 31, n. 1, p. 277-286, 2011. Disponível em: $<$ http://www.uel.br/revistas/uel/index.php/semagrarias/ article/view/3283>. Acesso em: 7 jul. 2014.
MATTOS, M. R.; BELOTI, V.; TAMANINI, R.; MAGNANI, D. F.; NERO, L. A.; BARROS, M. A. F.; PIRES, E. M. F.; PAQUEREAU, B. P. D. Qualidade do leite cru produzido na região do agreste de Pernambuco, Brasil. Semina: Ciências Agrárias, Londrina, v. 31, n. 1, p. 173-182, jan./mar. 2010.

NERO, L. A.; MATTOS, M. R.; BELOTI, V.; BARROS, M. A.; PINTO, J. P. A. N.; ANDRADE, N. J.; SILVA, W. P.; FRANCO, B. D. G. M. Leite cru de quatro regiões leiteiras brasileiras: perspectivas de atendimento dos requisitos microbiológicos estabelecidos pela instrução normativa 51. Ciência e Tecnologia de Alimentos, Campinas, v. 25, n. 1, p. 191-195, 2005.

NERO, L. A.; VIÇOSA, G. N.; PEREIRA, F. E. V. Qualidade microbiológica do leite determinada por características de produção. Ciência e Tecnologia de Alimentos, Campinas, v. 29, n. 2, p. 386-390, 2009.

OHI, M. Princípios básicos para a produção de leite bovino. Curitiba: UFPR, 2010. 144 p.

RECIO, I.; GARCÍA-RISCO, M. R.; RAMOS, M.; LÓPEZ-FANDIÑO, R. Characterization of peptides produced by action of psychrotrophic protease on $\kappa$ sein. Journal of Dairy Research, Copenhagen, v. 67, n. 4, p. 625-630, 2000.

RIBEIRO JÚNIOR, J. C.; TAMANINI, R.; GONZAGA, N.; MAREZE, J.; BELOTI, V. Micro-organismos termodúricos psicrotróficos com atividade proteolítica em leite cru refrigerado. In: SUL LEITE - SIMPÓSIO SOBRE SUSTENTABILIDADE DA PECUÁRIA LEITEIRA NA REGIÃO SUL DO BRASIL, 6., 2014, Maringá. Anais... Maringá: UEM, 2014. CD-ROM.

RIBEIRO JÚNIOR, J. C.; TAMANINI, R.; SILVA, L. C. C.; BELOTI, V. Quality of milk produced by small and large dairy producers. Semina: Ciências Agrárias, Londrina, v. 36, n. 2, p. 883-888, mar./abr. 2015.

SANTANA, E. H. W.; BELOTI, V.; BARROS, M. A. F.; MORAES, L. B.; GUSMÃO, V. V.; PEREIRA, M. S. Contaminação do leite em diferentes pontos do processo de produção: I. Microrganismos aeróbios mesófilos e psicrotróficos. Semina: Ciências Agrárias, Londrina, v. 22, n. 2, p. 143-154, 2001.

SANTANA, E. H. W.; BELOTI, V.; MULlER, E. E.; FERREIRA, M. A.; MORAES, L. B.; PEREIRA, M. S.; GUSMÃO, V. V. Milk contamination in different points of the dairy process: ii) mesophilic, psychrotrophic and proteolytic microorganisms. Semina: Ciências Agrárias, Londrina, v. 25, n. 4, p. 349-358, 2004. 
SILVA, L. C. C.; BELOTI, V.; TAMANINI, R.; OVIDIO, L.; MATTOS, M. R.; ARRUDA, A. M. C. T.; PIRES, E. M. F. Rastreamento de fontes da contaminação microbiológica do leite cru durante a ordenha em propriedades leiteiras do Agreste Pernambucano. Semina: Ciências Agrárias, Londrina, v. 32, n. 1, p. $267-$ 276, 2011.

TAMANINI, R. Controle de qualidade do leite UHT. 2012. Tese (Doutorado em Ciência Animal) Universidade Estadual de Londrina, Londrina.

TRONCO, V. M. Manual para inspeção da qualidade do leite. 3. ed. Santa Maria: UFSM, 2008. 206 p.
EUROPEAN UNION. Corrigendum to Regulation (EC) No 853/2004 of the European Parliament and of the Council of 29 April 2004 laying down specific hygiene rules for food of animal origin. Official Journal of the European Union, 29 April 2004. Available at: <http:// www.fsai.ie/uploadedFiles/Reg853_2004(1).pdf>. Accessed at: 30 may 2014.

VALLIN, M. V.; BELOTI, V.; BATTAGLINI, A. P. P.; TAMANINI, R.; FAGNANI, R.; ANGELA, H. L.; SILVA, L. C. C. Melhoria da qualidade do leite a partir da implantação de boas práticas de higiene na ordenha em 19 municípios da região central do Paraná. Semina: Ciências Agrárias, Londrina, v. 30, n. 1, p. 181-188, 2009. 